\title{
MODEL TRANSPORTASI DALAM MEMINIMUMKAN BIAYA DISTRIBUSI BERAS KEMASAN
}

\author{
V. S. Adoe 1 \\ 1Program Studi Teknik Informatika STIKOM Artha Buana Kupang \\ JIn. Samratulangi III No. 1 Walikota Kupang - NTT, 85111 \\ 1veraanwar08@gmail.com
}

\begin{abstract}
Rice is a strategic commodity that a very important role as the main staple food for the majority of people in Indonesia. Rice has its own distribution development pattern that provides added value to business actors. "CV. Hidup Baru Jaya" is a company in Kupang City that is engaged in distributing packaged rice from storage warehouses to several storage warehouses in other areas. In distributing the rice, the company tries to reduce or minimize the distribution costs incurred in order to obtain optimal profit. Mathematically, the transportation model is one solution that can be used to solve this rice distribution problem. By using POM-QM V4 as the optimal solution tool, it was found that the company could distribute 125 sacks of Raja Kupang rice to the Malaka Warehouse; 150 sacks of rice to Rote Warehouse, 75 sacks to Malaka Warehouse and 200 sacks to Atambua Warehouse for Stroberry rice; Nona Timor rice was 200 sacks to Semau Warehouse, 50 sacks to Rote Warehouse and 200 sacks to Sulamu Warehouse. Thus, the company profits Rp. 20,000,000, -.
\end{abstract}

Keywords : : Distribution Cost, Transportation Model

\section{ABSTRAK}

Beras merupakan salah satu komoditas strategis yang berperan sangat penting sebagai pangan pokok utama bagi ayoritas masyarakat di Indonesia. Beras mempunyai pola perkembangan distribusi tersendiri yang memberikan nilai tambah bagi pelaku usahanya. "CV. Hidup Baru Jaya" adalah salah satu perusahaan di Kota Kupang yang bergerak dalam pendistribusian beras kemasan dari gudang penyimpanan ke beberapa gudang penyimpanan di daerah-daerah lain. Dalam pendistribusian beras tersebut, perusahaan berusaha menekan atau meminimumkan biaya distribusi yang dikeluarkan untuk memperoleh keuntungan yang optimal. Secara matematis, model transportasi adalah salah satu solusi yang dapat digunakan untuk menyelesaikan masalah distribusi beras ini. Dengan menggunakan POM-QM V4 sebagai tools optimal solution diperoleh hasil bahwa perusahaan dapat mendistribusikan 125 karung beras Raja Kupang ke Gudang Malaka; Beras Stoberry sebanyak 150 karung ke Gudang Rote, 75 karung ke Gudang Malaka dan 200 karung ke Gudang Atambua; Beras Nona Timor sebanyak 200 karung ke Gudang Semau, 50 karung ke Gudang Rote dan 200 karung ke Gudang Sulamu. Dengan demikian, keuntungan yang diperoleh perusahaan sebesar Rp. 20.000.000, -.

\section{Kata Kunci : Biaya Distribusi, Model Transportasi}




\section{PENDAHULUAN}

Pangan berperan sangat penting bagi kehidupan manusia karena merupakan kebutuhan pokok dalam mempertahankan hidup manusia. Pangan yang dikonsumsi masyakarat Indonesia pada umumnya adalah beras, dimana beras masih menjadi makanan utama dan cenderung tunggal di berbagai daerah di Indonesia. Bagi masyarakat Indonesia, beras merupakan bahan makanan yang lebih superior daripada bahan pangan lainnya seperti jagung, ubi, sagu dan lainnya.

Indonesia sebagai salah satu negara penghasil sekaligus pengguna beras, menjadikan komoditas beras sebagai komoditas pangan yang paling strategis. Hal ini dikarenakan, beras dikonsumsi oleh hampir seluruh masyarakat, serta diproduksi oleh sebagian besar petani Indonesia. Akibat pentingnya beras bagi konsumen dan produsen, menyebabkan beras telah dianggap sebagai komoditas politik karena erat kaitannya dengan stabilitas ekonomi khususnya inflasi serta menjadi issu politik, jika terjadi kelangkaan beras. Berdasarkan data sensus statistik tahun 2020, diketahui bahwa produksi beras di Indonesia mencapai 54.469.202,24 ton, meningkat sebesar 99,92 \% dari tahun 2019 dengan jumlah produksi sebesar 54.604.033,34 ton, (www.bps.go.id). Dengan demikian stok atau ketersediaan beras secara nasional masih dapat memenuhi kebutuhan masyarakat Indonesia.

Produk beras yang beredar di masyarakat luas saat ini tidak hanya berupa beras raskin atau beras BULOG tapi juga berupa beras-beras kemasan dengan berbagai merek dan kualitas yang didistribusikan melalui perusahaan swasta seperti distributor, agen atau retail beras. Beras-beras kemasan tersebut dipasok dari Pulau Sumatera, Jawa dan Sulawesi. Salah satu distributor beras kemasan di Kota Kupang adalah "CV. Hidup Baru Jaya", yang memasok sebagian besar beras kemasannya dari Pulau Sulawesi. "CV. Hidup Baru Jaya" mendistribusikan beras kemasannya dengan cara menjual langsung pada pedagang grosir atau pengecer yang ada di Kota Kupang maupun dengan mendistribusikannya ke luar daerah seperti di Pulau Timor, Rote, dan Semau. Sebagai perusahaan swasta, tentunya CV. Hidup Baru Jaya mengharapkan keuntungan yang maksimal dari kegiatan distribusi beras tersebut.

Dalam mendistribusikan produk, perlu mempertimbangkan jalur distribusi dan jumlah atau unit yang akan didistribusikan. Disamping itu, perlu juga memperhitungkan biaya pengiriman yang lebih menguntungkan. Masalah dalam alokasi pendistribusian produk adalah bagaimana caranya agar produk tersebut dapat melewati jalur-jalur tertentu, dari sumber-sumber yang menyediakan produk ke tempat-tempat tujuan, sehingga biaya yang dikeluarkan dapat ditekan seminimal mungkin. Pengiriman produk dapat dikatakan optimal jika didukung dengan adanya rencana pengalokasian yang tepat, sehingga akan menghasilkan biaya transportasi yang minimum. Adapun alat bantu trasportasi yang dapat digunakan berupa transportasi darat, transportasi laut, dan transportasi udara, (Chandra, 2016).

CV. Hidup Baru Jaya mendistribusikan beras kemasannya menggunakan transportasi darat dan transportasi laut ke daerah-daerah tujuan. Dengan demikian pihak perusahaan perlu membuat 
suatu perencanaan secara matang agar biaya transportasi yang dikeluarkan seefisien mungkin dan tidak menjadi kendala dan menghambat aktivitas operasional pendistribusian yang dapat menguras biaya besar. Menurut Riniwati (2020), model linier programming metode transportasi merupakan salah satu metode yang dapat digunakan dalam menganalisis keuntungan yang maksimal atau optimal dari sisi minimalisasi biaya distribusi pemasaran.

Berdasarkan latar belakang yang diuraikan diatas maka permasalahan yang terjadi adalah bagaimana pihak perusahaan dapat mengoptimalkan biaya distribusi beras ke daerah-daerah tujuan sehingga memperoleh keuntungan yang maksimal ?. Untuk itu, tujuan yang ingin dicapai adalah pengoptimalan biaya distribusi beras ke daerah-daerah tujuan sehingga perusahaan memperoleh keuntungan yang maksimal.

\section{METODE PENELITIAN}

\subsection{Prosedur Penelitian}

Penelitian ini dilaksanakan pada Gudang Beras CV. Hidup Baru Jaya yang berlokasi di Jalan Yos Sudarso, Kecamatan Alak Kota Kupang. Teknik pengumpulan data dilakukan dengan menggunakan beberapa metode antara lain :

1. Observasi atau pengamatan langsung prosedur dan proses pengiriman beras, dari pengangkutan beras ke atas truck-truck angkut di gudang hingga pada truck meninggalkan gudang penyimpanan atau penampungan.

2. Wawancara dan pengisian kuisioner dengan pemilik perusahaan maupun karyawan/pekerja pada CV. HIDUP BARU JAYA.

Adapun data-data yang dibutuhkan untuk penelitian ini berupa data :

a. Jenis beras yang tersedia dalam gudang penyimpanan (gudang sumber/origin/sup/y).

b. Daerah-daerah yang menjadi tujuan pengiriman atau distribusi beras (gudang tujuan/destination/demand).

c. Jumlah beras yang tersedia di gudang sumber per jenis beras dan jumlah permintaan beras dari setiap gudang tujuan per jenis beras.

d. Harga beras per karung untuk setiap jenis beras.

e. Rata-rata biaya distribusi dan rata-rata keuntungan yang diperoleh.

Data yang dikumpulkan, kemudian dianalisis menggunakan aplikasi POM-QM untuk mengetahui hasil yang optimal.

\subsection{Metode}

\subsubsection{Model Transportasi}

Model transportasi merupakan suatu bentuk model Linear Programming yang dapat digunakan dalam menyelesaikan masalah transportasi, misalnya dalam mengatur distribusi produk yang sama (homogen) dari sumber yang menyediakan produk ke tempat-tempat yang membutuhkan produk tersebut secara optimal. Dikarenakan adanya perbedaan biaya-biaya 
alokasi dari satu atau beberapa sumber ke tempat-tempat tujuan yang berbeda-beda, maka alokasi produk pun perlu diatur sedemikian rupa.

Syaifuddin T (2011), mengemukakan bahwa model transportasi merupakan salah satu model program linier yang mempunyai karakteristik khusus, yaitu: produk didistribusikan dari beberapa sumber ke beberapa tujuan dengan biaya minimum yang mungkin; setiap sumber dapat memasok dengan pasti sejumlah produk; setiap tujuan memiliki permintaan yang pasti. Permasalahan yang diselesaikan dari model transportasi adalah persoalan pendistribusian barang dari beberapa sumber ke beberapa tujuan dengan biaya minimum, yang mana persoalan ini sering dijumpai pada industri manufaktur maupun jasa. Persoalan model transportasi pada umumnya dapat diselesaikan menggunakan 2 jenis metode, yaitu metode solusi awal dan metode solusi optimum, (Kusumawardani, 2017).

M. Trihudiyatmanto (2017), menjelaskan ciri-ciri dari metode transportasi antara lain :

1. Terdapat sejumlah sumber dan tujuan tertentu.

2. Kuantitas komoditi/barang yang didisitribusikan dari setiap sumber dan yang diminta oleh setiap tujuan besarnya tertentu.

3. Komoditi yang dikirim/diangkut dari suatu sumber ke suatu tujuan besarnya sesuai dengan permintaan dan atau kapasitas sumber.

4. Ongkos pengangkutan komoditi dari suatu sumber ke suatu tujuan besarnya tertentu.

\subsubsection{Matriks Transportasi}

Model matematis transportasi adalah sebuah matriks transportasi yang memiliki $\mathrm{m}$ baris dan $\mathrm{n}$ kolom. Sumber-sumber berjajar pada baris ke-1 hingga ke-m, sedang tujuan-tujuan berbanjar pada kolom ke1 hingga ke-n.

Dengan demikian:

Xij : satuan barang yang akan diangkut dari sumber i ke tujuan j.

bij : biaya angkut per satuan barang dari sumber i ke tujuan $\mathrm{j}$.

Sehingga secara matematis dapat dirumuskan sebagai berikut :

$$
\operatorname{Min} \sum_{i=1}^{m} \sum_{j=1}^{n} b_{i j} X_{i j}
$$

Pada matrik transportasi sumber-sumber terletak pada baris, sedangkan tujuantujuan terletak pada kolom, (Mangapul \& Raja, 2018). Model matrik transportasi digambarkan pada Gambar 1. 


\begin{tabular}{|c|c|c|c|c|c|}
\hline \multirow{2}{*}{ Sumber } & \multicolumn{4}{|c|}{ Tujuan } & \multirow{2}{*}{$\begin{array}{c}\text { Kapasitas } \\
\text { sumber per } \\
\text { periode }\end{array}$} \\
\hline & $\mathrm{T}_{1}$ & $\mathrm{~T}_{2}$ & ............ & $\mathrm{T}_{\mathrm{n}}$ & \\
\hline $\mathrm{S}_{1}$ & $\mathrm{X}_{11} \mathrm{C}_{11}$ & $\mathrm{X}_{12} \mathrm{C}_{12}$ & $\cdots$ & $\begin{array}{l}\mathrm{C}_{1 \mathrm{n}} \\
\mathrm{X}_{\ln }\end{array}$ & $\mathrm{B}_{1}$ \\
\hline $\mathrm{S}_{2}$ & $\mathrm{X}_{21}^{\mathrm{C}_{21}}$ & $\mathrm{X}_{21} \mathrm{C}_{21}$ & $\cdots \cdot$ & $\begin{array}{l}\mathrm{C}_{2 n} \\
\mathrm{X}_{2 \mathrm{n}}\end{array}$ & $\mathrm{B}_{2}$ \\
\hline $\mathrm{S}_{\mathrm{m}}$ & $\mathrm{X}_{\mathrm{ml}}{ }^{\mathrm{C}_{\mathrm{ml}}}$ & $\mathrm{X}_{\mathrm{m} 2}{ }^{\mathrm{C}_{\mathrm{m} 2}}$ & $\cdots$ & $\begin{array}{l}\mathrm{C}_{\mathrm{mn}} \\
\mathrm{X}_{\mathrm{mn}}\end{array}$ & $\mathrm{B}_{\mathrm{m}}$ \\
\hline Kebutuhan tujuan & $\mathrm{P}_{1}$ & $\mathrm{P}_{2}$ & $\cdots \cdots \cdots$ & $P_{n}$ & $\sum \mathrm{Pj}_{\mathrm{j}}$ \\
\hline
\end{tabular}

Gambar 1 : Matriks Transportasi

$S=$ Sumber produk itu berasal

$T=$ Tempat tujuan dari produk tersebut

$C=$ Biaya angkut per unit produk dari sumber ke tempat tujuan

$\mathrm{X}=$ Jumlah produk yang didistribusikan

$\mathrm{B}=$ Jumlah keseluruhan kapasitas dari sumber/pabrik

$\mathrm{P}=$ Jumlah keseluruhan permintaan

\section{HASIL DAN PEMBAHASAN}

\subsection{Hasil}

Pengumpulan data lapangan dari hasil observasi, wawancara dan pengisian kuisioner dengan pemilik dan karyawan atau pekerja pada CV. Hidup Baru Jaya kemudian ditabulasi seperti pada Tabel 1 berikut:

Tabel 1 : Data Biaya Distribusi Dari Sumber Ke Tujuan Pengiriman

\begin{tabular}{|c|c|c|c|c|}
\hline \multicolumn{5}{|c|}{ CV. HIDUP BARU JAYA } \\
\hline $\begin{array}{c}\text { Tujuan } \\
\text { (Gudang) }\end{array}$ & $\begin{array}{c}\text { Biaya Beras } \\
\text { Udang } \\
\text { (Rp/Karung) }\end{array}$ & $\begin{array}{c}\text { Biaya Beras } \\
\text { Raja Kupang } \\
(\text { Rp/Karung) }\end{array}$ & $\begin{array}{c}\text { Biaya Beras } \\
\text { Strobery } \\
\text { (Rp/Karung) }\end{array}$ & $\begin{array}{c}\text { Biaya Beras } \\
\text { Nona Timor } \\
\text { (Rp/Karung) }\end{array}$ \\
\hline Semau & 390.000 & 390.000 & 390.000 & 390.000 \\
\hline Rote & 385.000 & 385.000 & 385.000 & 385.000 \\
\hline Malaka & 380.000 & 380.000 & 380.000 & 380.000 \\
\hline Atambua & 380.000 & 380.000 & 380.000 & 380.000 \\
\hline Sulamu & 390.000 & 390.000 & 390.000 & 390.000 \\
\hline
\end{tabular}

Sumber : Data Olahan CV. Hidup Baru Jaya, 2020.

Pemilik usaha menjelaskan bahwa biaya distribusi sekali alokasi telah diakumulasikan ke dalam harga beras per karungnya. 
Tabel 2 : Data Jumlah Permintaan Beras Dari Sumber Ke Daerah Tujuan Pengiriman

\begin{tabular}{|c|c|c|c|c|c|}
\hline \multicolumn{5}{|c|}{ Tujuan Pengiriman } & Persediaan \\
\hline Semau & Rote & Malaka & Atambua & Sulamu & \multirow{2}{*}{70 ton } \\
\hline 8 ton & 8 ton & 8 ton & 8 ton & 8 ton & \\
\hline Permintaan & \multicolumn{4}{|c|}{40 ton } & \\
\hline Keuntungan & Rp $20.000 /$ karung (40kg) \\
\hline
\end{tabular}

Sumber : Data Olahan CV. Hidup Baru Jaya, 2020.

Dari data tersebut kemudian dimasukkan ke dalam bentuk matrik sebagai berikut :

Tabel 3 : Matriks Transportasi Beras

\begin{tabular}{|l|c|c|c|c|c|c|}
\hline \multirow{2}{*}{ Beras } & \multicolumn{5}{|c|}{ Gudang } & \multirow{2}{*}{ Persediaan } \\
\cline { 2 - 6 } & Semau & Rote & Malaka & Atambua & Sulamu & \\
\hline Udang & 390.000 & 385.000 & 380.000 & 380.000 & 390.000 & 18 Ton \\
\hline $\begin{array}{l}\text { Raja } \\
\text { Kupang }\end{array}$ & 390.000 & 385.000 & 380.000 & 380.000 & 390.000 & 17 Ton \\
\hline Stroberry & 390.000 & 385.000 & 380.000 & 380.000 & 390.000 & 17 Ton \\
\hline Nona Timor & 390.000 & 385.000 & 380.000 & 380.000 & 390.000 & 18 Ton \\
\hline Permintaan & 8 Ton & 8 Ton & 8 Ton & 8 Ton & 8 Ton & $\begin{array}{l}\text { 45 Ton I 70 } \\
\text { Ton }\end{array}$ \\
\hline
\end{tabular}

Matriks di atas, lalu dianalisis untuk mendapatkan hasil penyelesaiannya dengan menggunakan aplikasi POM-QM for Windows V4. Adapun langkah-langkah dalam penggunaan aplikasi sebagai berikut :

1. Aktifkan aplikasi POM-QM for Windows V4, kemudian memilih module transportation seperti tampilan berikut :

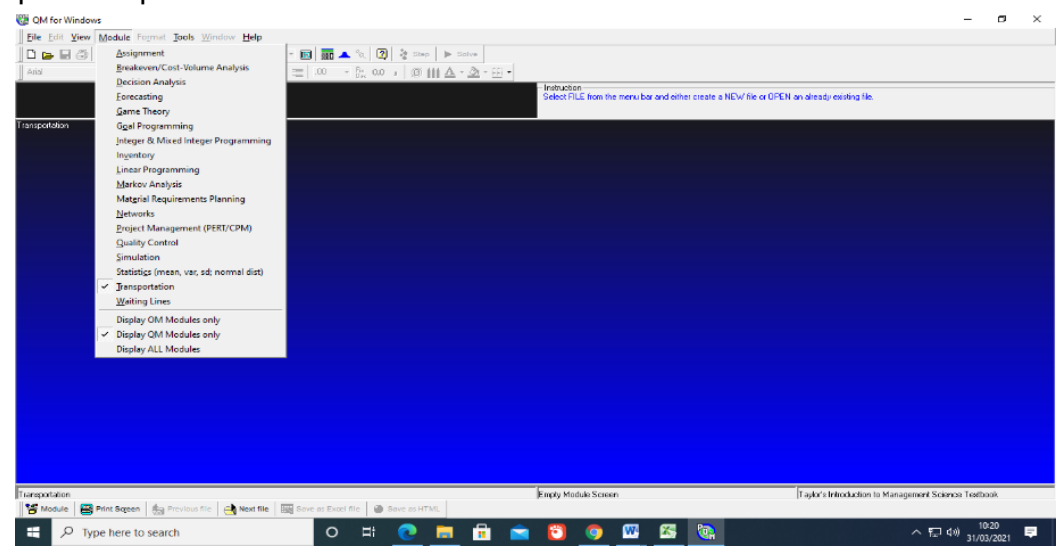

Gambar 1 : Tampilan Awal Program POM-QM 
2. Masukan semua data dalam matriks ke dalam aplikasi sebagai berikut :

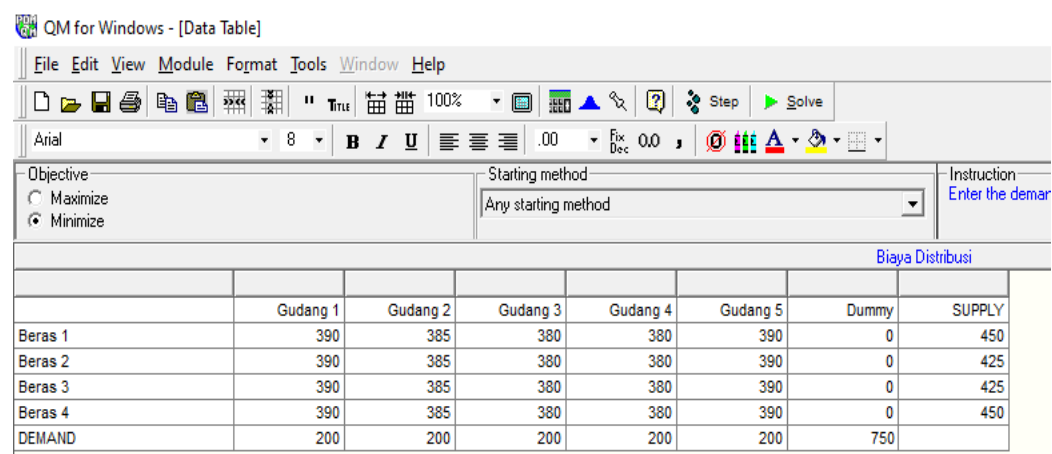

Gambar 2 : Tabel Data POM-QM

3. Langkah terakhir adalah menganalisis data yang telah dimasukkan dengan menggunakan solve button untuk mendapatkan hasil atau solusi yang optimal seperti Gambar 3,4 , dan 5.

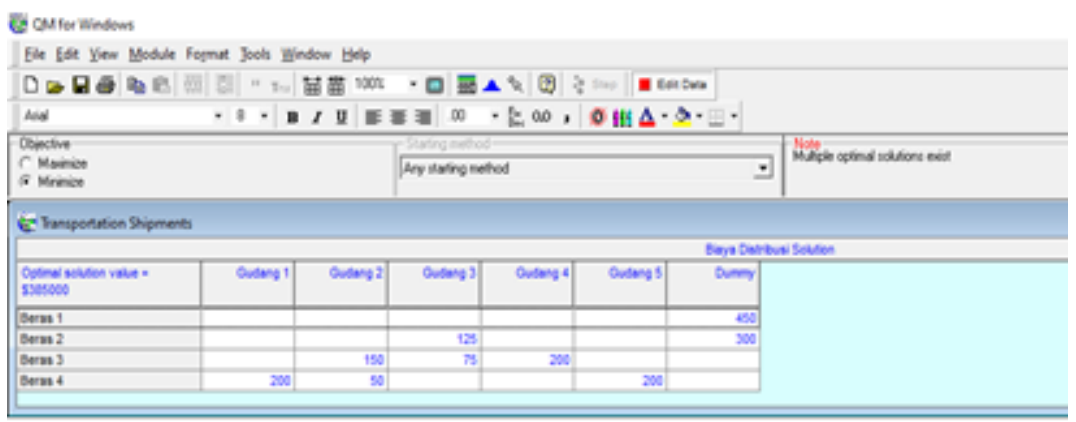

Gambar 3 : Transportation Shipments

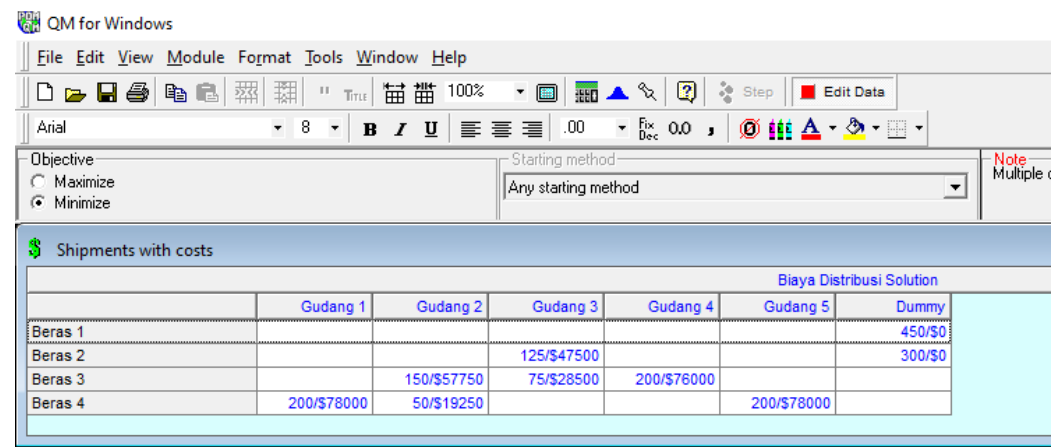

Gambar 4 : Shipments with costs 


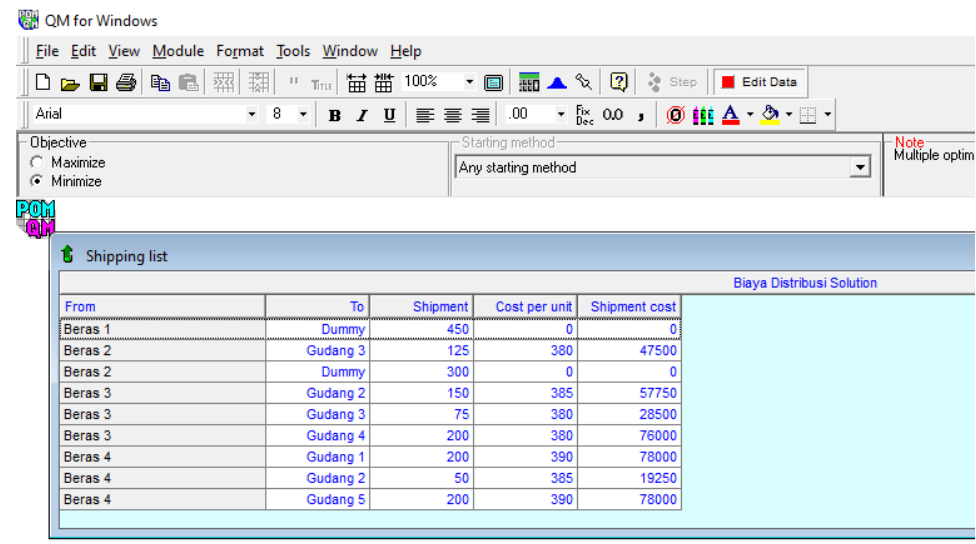

Gambar 5. Shipments List

\subsection{Pembahasan}

Dari data yang diperoleh perusahaan bahwa beras kemasan yang dijual semua dalam bobot yang sama yaitu $40 \mathrm{~kg} / \mathrm{karung}$. Untuk biaya distribusi beras tersebut tidak dihitung per $\mathrm{kg}$ tapi dihitung per karung, dimana biaya tersebut telah dianggarkan dengan menaikkan biaya atau harga jual beras per karung seharga Rp. 390.000/karung untuk distribusi ke Gudang Semau dan Gudang Sulamu, Rp. 385.000/karung untuk distribusi ke Gudang Rote dan Rp. 380.000/karung untuk distribusi ke Gudang Malaka dan Gudang Atambua.

Hasil analisis menunjukkan bahwa perusahaan mendistribusikan berasnya sebagai berikut : 125 karung (5ton) beras Raja Kupang ke Gudang Malaka sisanya 300 karung (12ton) tetap dalam Gudang Kupang untuk didistribusikan ke grosir dan retail di wilayah Kota Kupang. Beras Stoberry didistribusikan sebanyak 150 karung (6ton) ke Gudang Rote, 75 karung (3ton) ke Gudang Malaka dan 200 karung (8ton) ke Gudang Atambua. Beras Nona Timor didistribusikan sebanyak 200 karung (8ton) ke Gudang Semau, 50 karung (2ton) ke Gudang Rote dan 200 karung (8ton) ke Gudang Sulamu. Sedangkan Beras Udang sebanyak 450 karung (18ton) akan didistribusikan ke tempat yang sama dengan Beras Raja Kupang sehingga tetap dalam penyimpanan di Gudang Kupang. Adanya kolom dummy dalam analisis disebabkan karena jumlah yang diminta tiap Gudang berbeda dengan jumlah stok atau jumlah beras yang tersedia sehingga perlu diseimbangkan antara pemintaan (demand) dan penawaran (supp/y). Hal ini terlihat jelas pada Gambar 3.

Bervariasinya jumlah dan merek beras yang didistribusikan perusahaan dikarenakan adanya persaingan antar perusahaan dalam kualitas (merek) dan harga beras. Masing-masing beras memiliki pangsa pasarnya sendiri. Oleh karena itu, distribusi beras disesuaikan dengan tingkat penjualan dari masing-masing merek beras.

Total penjualan beras dari perusahaan CV. Hidup Baru Jaya adalah (125 x Rp. $380.000 .,-)+(150 \times$ Rp. $385.000,-)+(75 \times$ Rp. 380.000,-) + (200 x Rp. 380.000,-) + (200 x Rp. 
390.000,-) + (50 x Rp. 385.000,-) + (200 x Rp. 390.000,-) = Rp. $47.500 .000+$ Rp. 57.750 .000

+ Rp. $28.500 .000+$ Rp. $76.000 .000+$ Rp. $78.000 .000+$ Rp. $19.250 .000+$ Rp. $78.000 .000=$ Rp. 385.000.000,--

Apabila rata-rata keuntungan beras yang diperoleh perusahaan sebesar Rp 20.000,-I karung maka total keuntungan yang diperoleh perusahaan dari distribusi beras ke gudanggudang penyimpanan di daerah tujuan sebesar $(125+150+75+200+200+50+200)$ karung x Rp. 20.000,- = 1.000 karung x Rp. 20.000,- = Rp. 20.000.000,-. Dengan demikian keuntungan yang diperoleh perusahaan sebesar Rp. 20.000.000,-. Keuntungan yang diperoleh perusahaan dari penjualan beras dalam wilayah Gudang Kota Kupang sendiri akan lebih besar mengingat biaya distribusi yang dikeluarkan pun lebih sedikit karena hanya mengunakan transportasi darat dan jarak tempuh yang tidak jauh seperti ke Gudang Makala dan Gudang Atambua.

\section{KESIMPULAN}

Model transportasi adalah salah satu model yang tepat dalam menyelesaikan masalah distribusi, yang mana perusahaan berupaya meminimumkan biaya transportasi yang dikeluarkan dalam pendistribusian produk dari gudang sumber ke gudang tujuan guna mengoptimalkan keuntungan yang diperoleh. Aplikasi POM-QM For Windows 4 ini yang dapat digunakan sebagai tools atau alat untuk mencari solusi dari bentuk masalah transportasi. Dari hasil analisis diperoleh bahwa apabila perusahaan mendistribusikan 125 karung beras Raja Kupang ke Gudang Malaka; Beras Stoberry sebanyak 150 karung ke Gudang Rote, 75 karung ke Gudang Malaka dan 200 karung ke Gudang Atambua; Beras Nona Timor didistribusikan sebanyak 200 karung ke Gudang Semau, 50 karung ke Gudang Rote dan 200 karung ke Gudang Sulamu, maka perusahaan akan memperoleh keuntungan sebesar Rp. 20.000.000,--

\section{DAFTAR PUSTAKA}

[1]. Chandra, T., Penerapan Algoritma North West Corner Dalam Penyelesaian Masalah Transportasi, 2016, Jurnal TIMES, V (1), 12-16. http://stmik-time.ac.id/ ejournal/ index.php/ jurnalTIMES/ article/view/393/106.

[2]. Kusumawardani, R., Optimization of Transportation Cost Using Genetic Algorithm, 2017, Jurnal Eksakta, 17(1), 33-45. https://doi.org/10.20885/eksakta.vol17.iss1.art4

[3]. M. Trihudiyatmanto., Riset Operasional (Operations research) \& Penyelesaian menggunakan Softwere WinQSB. December 2018, 2018, 137. https://www.academia.edu/ 33225674/ Riset_Operasional_Operations_research_and_Penyelesaian_menggunakan_Softwere_ WinQSB

[4]. Mangapul, J., \& Raja, V. L., Menentukan Biaya Minimum Pengiriman Barang Ekspor Dengan Metode Model Transportasi, 2018, Jurnal Teknikunkris. Ac. Id, 431-435. 
https://jurnal.teknikunkris.ac.id/index.php/SEMNASTEK/article/viewFile/72/68.

[5]. Riniwati, H. dkk., Model Optimasi Distribusi Pemasaran Produk Olahan Ikan Lele, 2020, ECSOFiM, 8(1), 67-81. https://doi.org/10.21776/ub.ecsofim.2020.008.01.06

[6]. Syaifuddin T, D., Riset Operasi (Aplikasi Quantitative Analysis for Management), 2014, (p. 147). Citra Malang. 